\title{
The Main Motives and Objectives of Fun Genre in Folklore
}

\author{
Adizova Nigora Bakhtiyorovna
}

\begin{abstract}
Players play an important role in the spiritual development of children. They prepare the child to interact with the outside world. It introduces you to the surroundings. It serves to develop a child's fantasy. The toys are played to entertain children and broaden their outlook. One of the most important tasks of the fun is that it helps children to understand the nature of social issues, class relations, and some philosophical categories. It contains essentially important life and education issues. That doesn't seem to be boring to children.Funs are often told about random funny events and funny situations. So humor and fun play an important role in them. Funs are like adults playing games with children. Although they are created by adults, children are still an example of folk poetry.
\end{abstract}

Keywords : fun, motivation, image, song, intro, episode, plot, legend, fairy tale, myth, trick, talmex, poem s.

\section{INTRODUCTION}

$\mathrm{W}_{\mathrm{e}}$ focus on collecting, publishing and exploring sources reflecting the historical and poetic evolution of genres associated with folklore, designed to raise children, their artistic thinking and aesthetic taste in world folklore.

\section{MATERIAL AND METHODS}

This Studying funs will allow you to identify the types of traditional children's songs that are commonly found in folklore and to gain a deeper understanding of the specific poetic development of children's folklore.

Examples of fun genre are funny little poetic stories that are based on interesting and sophisticated stories, whispering, screaming, and humor. Funny expression, humorous meaning plays an important role in fun.

\section{LITERATURE REVIEW}

"Baby Song" by Elbek for the article O.Safarov "Boychechak" collection Y. Sultanov selected 8 hints in 161 lines from the Ferghana Valley and 135 lines from Sabir Ehson Turk Khorezm oasis. Historical-comparative, comparative-typological, ethnofolkloristic and linguistic methods were used in the coverage of the topic.

The funs are educational and aesthetic in nature, and are integrated with folk pedagogy because they are designed to direct the child to life, to tell him something, to teach, to

Revised Manuscript Received on October 15, 2019.

* Correspondence Author

Adizova Nigora Bakhtiyorovna*, Senior lecturer of Bukhara State University. enrich his imagination and understanding.

Thus it is understood that funs have passed the stage of spiritual and artistic development.The art of the fun differs from that of the other pampering songs. Therefore, they play an important role in aesthetic education of children. They use traditional images that are clear and understandable to children.

\section{ANALYSIS}

In funs, the reality is that one event connects with the other and forms an intellectual chain link. They also have a shift from image to image, from idea to thought. Although the toys are designed for children, they also have an adult image. It also shows how people, animals, and events are represented in the fun. Therefore, the world of funs is diverse. It is one of the most common images in strangers. They are often criticized for being bad-looking. Especially unpretentious, unreasonable newcomers are exposed:

The white stone of Astana

Pencil of my Sister-in law.

You're still fresh, You can't cut clothes,

Wear your clothes, You don't go to the Khan.

Before marriage, girls should learn how to manage household chores, especially cooking and sewing. Otherwise, they will be reproached wherever they go.

In this curiosity, it is said that the fatigue of the yoke, the food the husband puts on the hack, is broken. Folklore writer A.Musakulov writes that "the lyric side of the Uzbek folklore is an artistic expression that expresses the certainty of shamanism." Because the hawk is often portrayed as a symbol of evil. And the cheek (shaman) is a fighter against evil. That is why the Hakka always pursues and harms his adversary (candle) as an embodiment of evil. Often it hurts his loved ones, not him. I $t$ is known that windows, water, fish, millet, chicken and its eggs are the most commonly used items by candles. Therefore, it is no coincidence that they are presented in the form of a touch art in a curiosity based on the image of the yang.

\section{DISCUSSION}

A.Musakulov says: "Shamanic poetry is one of the most important historical bases in the formation and development of lyrical species in the oral traditions of the Turkic peoples."

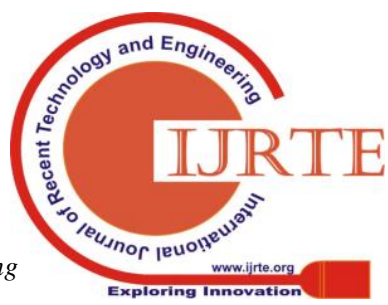


Artistic expression of rudimentary observations can be observed. This also applies to funs in children's folklore.

If you compare the above-mentioned fun with the story of the Uzbek folk tale, "The Craft That Has No World," they will have their own meaningful intimacy and similar images. For example, in this fairy tale, a king's daughter makes a decision to marry only a man who knows nothing of the world. Only a young man who has been sold by his mother as a sucker for witchcraft can fulfill this condition. This is because the witch's daughter has compassion for the young man and teaches her more than the tricks of her own people. The guy uses this to become a dove to avoid the witch. The witch turns into a raven to catch him. The witch turns into a raven to catch him. When a man turns into a flower, a witch in the form of a goat turns into a pleasant lady. When the guy turns into a mill, the witch turns into a chicken. The young man immediately turns into a jackal, eats a witch in the form of a chicken and returns to his own. [7,202-207] It appears that both the bird and the fairy tale, the chicken and the goat, the chicken and the chicken are represented in the same sequence. Funny cheat is also common in cheats, which is a type of fun:

As it is known, a rod or a whip is one of the main ritual subjects of candles and saints. Hassa is often used as a symbol of divine power, while the whip is the main weapon of the candle.

According to Levirat's custom, if a brother dies early in the family, his children will marry the brother-in-law, so that his children will not be disgraced. a cup of water ", it is not hard to see that it refers to this custom.

The elder is represented by the grandmother and the grandfather. The fun is being mocked by an elder, a man who sells water and pursues personal wealth. His bird example is exposed, his hatred and selfishness are revealed. Another of the most popular personality figures is the image of the Khan:

What's next to the Khan?

There are flying birds.

Flying into the air,

Returned to the river.

Let the river dry up,

Let the fish rot.

Hasan-Husan struck,

They were red-blooded.

Who drank red blood?

The elder grandfather drank.

Through the first three lines of the fun, the essence of the khan's system is revealed. It is revealed that it is useless to complain to the khan and complain about what happened to them.

The expression "Let the river dry, the fish rot" is actually a curse on the khans. It expresses the wish of the khans to perish through the very foundations of the khanate system.

In the following verse, "Hasan-Husan was beaten, painted red-blood, who drank red blood," refers to the frequent fraternity wars between the khanates in the crusade.

The daughter of the Khan did not stay;

He did not wash his hands.

He didn't greet the Khan,

Hello, brother!

In these poems the last lines of the quirk that begins with

"Camels, Camels,

Where Is Your Home?"

I found a handle.

I gave the color to the Khan,

The Khan gave me a sword.

I threw the sword into the water.

In the past, the actions of the people were taken away by the tyrannical khans to enrich their treasure. Then, in exchange for the wealth of the people, the army gathered and carried on the invasion wars. There is a booty made by walking on peaceful countries. The first and second lines of this poetic text referring to this historical reality are said to give the khan all the work of the hard-working people, and in the following verses the khan devours the sword and leads them to war. But the steadfast people are finally rebelling and throwing their swords into the water, refusing to go to war, and trying to live a clear, peaceful life. Some myths include the mythological space and mythological images:

Let's get to the Eram Garden.

There is a bar in the Eram garden,

Gulnor opa.

Let Pari not see you,

Do not fall in love.

If you are in love,

Happy Lily.

Set fire to the mountain,

Play around.

In legends and fairy tales, the Eram Garden is interpreted as a place of wigs. Pari's image plays a special role in the mythology of the peoples of Central Asia. For example, in the text of the Uzbek folk legends, fairy tales, and poems, this image is often used. The genesis and poetics of Pari's image in Uzbek folklore have been specially investigated by $\mathrm{O}$. Kayumov as a candidate's work. $[9,25]$ It is known that in the poems of the series "Gorgogo" the name of a pari Gulnor is mentioned. She is one of Goroglu's wives, and in the series of poems a separate poem "Gulnor Pari" was created. Among our people there are those who give their daughter a good name. But in reality, people treat the feathers with fear. That is why the poem is addressed to a girl named Gulnor "that she has something to look at and that she will not fall in love." Because people believe that feathers help or hurt a person. Folk epic works often portray a fairy-tale girl who falls in love with a character. If a person wants to talk about it to someone else, he will be punished severely. This means that such attitudes are also embedded in the content of the fun for children. The text also refers to the legendary lovers Lailey and Majnun, and you can see that the tales were created. 
This is to emphasize the advantage of falling in love with a man rather than in love with man and fairy. Apples are one of the most common types of carnivores. For example: "Who is on the roof?" - There is Nigorakhon. - What are you doing? The apple is giving away. "Just one." - His mother is beating. "Don't let the mother fight!" Do not cut apples too early!

In folk art, the apple is often thought of as the symbol of a child or a child. In the text above, it is hidden from the heart of the wish that the apple does not interrupt, so that the mother does not lose her baby. He tells this curious boy that he feels involuntarily standing on the roof, picking apples from the roof, and laughing with delight. In the fun, the ancient Uzbek houses, with their horns on the roofs of the lawn, are appropriately decorated with fried apple fruit. Moreover, the choice of this fact is not accidental. The roof here is a sign of height. Not only did the singer say, "I lifted you above my head," but instead of using the word "loud" based on a spiritual connection, he increased the artistic appeal of the song. In the text, the mother's resistance to apples draws particular attention to the motivation for children not to eat in the song "Dumplings Boiling". But this does not mean that the mother's hatred is not expressed, but rather that the song ends with a poem of goodwill. There is another variant of this curiosity that states that the mother, rather than the mother, is opposed to the apples being served: The moon in the sky,

Our Dilbaroy!

- What are you doing?

- I eat apples.

- Give it away,

- My brother is beating.

- Let your brother die,

God forbid.

Let the yard sink,

Let the girls play. [10,54]

The older men always protect the honor and dignity of their sisters. Such brothers are welcomed in the text.

The sun has gone out, the pot has ripened, Apples are ripe in the plum. I stumbled, I stumbled, one fell, He escaped. At first glance, this curiosity seems to have nothing to do with the pot of the day, both the apple and the ripe apple. But in reality they are logically interrelated. It is not accidental that at the beginning of the poem the image of the sun (sun) is brought. Because the sun shines on everything in existence and gives life. Even a fire that contributes to ripening is viewed as a piece of sun. Because in the mythology of the world it is understood that Prometheus brought fire from the sun. Therefore, it is difficult to deny that the images of day and night are presented in the first verse of the poem, not merely because of their vocal harmony, but because they point to this belief.

It is no coincidence that the image of Allatag is added to the next line. People thought that the sun was behind the mountain. Therefore, mountain apples that are close to its light are described as mysterious. Indeed, mountain apples are generally known for their taste in garden apples. The mysterious apple that escaped such an apple is also mysterious. No matter how much the apple owner pursues it, he cannot. Because the forward also represents a different space. Water space separates and surrounds human space with:

I was chased, I could not chase, I could not cross the river. Finally, the hero encounters a shepherd on his way to the pursuit of the mysterious apple. The shepherd gives him a stick and meat: A shepherd went out with me, I gave the shepherd a stick. Shepherd gave me meat. The hero gives the meat to the mother and gives the beef in return: I gave the meat to my mom. Mom gave me a bead. She gives the girl a necklace that she gives her. And she gave him a testicle, an egg in return: I took the bead and gave it to the girl. The girl gave me a testicle.

The shepherd is also one of the most popular characters in the fun. Livestock is one of the most ancient occupations of our people and our ancestors have been engaged in pastoral work since ancient times. Livestock farming is considered to be ancient. There were different types of livestock between the grassland and the half-population. Livestock shepherds usually drive the herd to mountain pastures or steppe meadows or steppe meadows after calving.

Shepherding is a mysterious profession. So far as pastors have followed their pamphlet, they have faith in their pirates. [2,109-113] Shepherds have their own superstitions, beliefs, and professional experience. In particular, they need to have a good knowledge of the nature of the animals they feed, the low and high grazing areas, the pastoral calendar, and the rituals associated with their occupations. The profession of shepherding is continued in accordance with the tradition of mentor-apprentice. Generally, young shepherds have been taught what they know.

Not all shepherds are shepherds. A shepherd's rod is not for everyone. To do this, first of all, you need to be experienced, sincere, and diligent in public trust. The people trust and respect as their shepherd only those who have been tested by the people, who possess the mysteries of shepherding.

Shepherds are very trustworthy and responsible, especially for their wand. They do not give or give up their rods to anyone. They lie next to them on their beds or beneath their heads. That is why there is a system of religious beliefs and rituals associated with the shepherd's staff. A shepherd's rod is a support, protection, and helper for the shepherd. Shepherds are usually made from fruit trees. It is intended to increase my wealth. Shepherds often use sticks in hardwood, such as hardy, fruity, fructose, hawthorn, and groves. The sticks from these trees were not easily decayed and were able to serve their owners for many years. It is observed that the religious beliefs associated with the shepherd's rod are specifically expressed in folk tales. These include, "Know the shepherd by the rod, and the bride's foot," and "the shepherd's staff is the horse's foot." 
Apparently, these folk tales emphasize the combination of "shepherd's rod". In the first article, if a shepherd's rod is taken from a tree, and the shepherd is faithful, hardworking, dedicated, agile, and agile, he will feed more. On the contrary, if a shepherd's rod is taken from an unproductive tree or the shepherd is incapable of doing his job, the cattle are said to be ruined. Also, the bride is "hands and feet" and is happy to have her run and serve. Hence, the shepherd and the bride need agility, dedication, dedication, and love for the job.

In the second poem, the shepherd's wand is compared to his horse's leg, because the shepherd travels in many places according to his profession. He sees a lot in his way. $\mathrm{He}$ witnessed many events. Therefore, in the articles he is like a man who rides a horse. When a horse rides a long distance, the shepherd crosses it on foot. In this sense, the shepherd compares the distance that the shepherd uses to his foot to the distance traveled by the horse's hard hooves, recognizing their fatigue, endurance, and strength.

There is another option for this article. It is called "The Shepherd's Wand - the Marketer's Feet". In this article, it is no accident that a shepherd's rod is compared to a marketer's foot. Because when you enter the market, your legs get tired until you find what you are looking for in the marketplace. Hence, this article also points to the shepherd's long walk on the heel, and it emphasizes the shepherd's support. Although shepherds look like a rod, they are not called a cane. It is always called a "shepherd's rod." A shepherd's rod is a luxurious long wooden stick.

In the famous folk tale called Guliqahkah, there is the image of a shepherd stick. in the fairy tale, it is equated with a mirror. In the fairy tale, the hero gets a shepherd's rod. It is said to have a mirror on a stick. It is no coincidence that in the fairy tale the phrase "there is a mirror on a shepherd's rod". As you know, in the fairy tale world, the world of mirrors is a strange subject that informs us of what is happening around the world.

This peculiar task is not accidentally transferred to the image of a shepherd's wand. People who carry a shepherd's stick often see, hear, and hear. If anyone is talking to them, they are aware of many things. Therefore, in fairy tales and legends, when heroes need information about a particular place or something, they go to the shepherd and ask for his advice. Suffice it to remember the plot of the fairytale tale "Ur To'qmoq". Generally, in fairy tales the image of a pastor is presented as an educated, educated person. Often when an epic hero goes on a journey to find what he has lost, he has the motivation to approach the pastor and ask for guidance and advice. A similar situation can be observed in the text of the quote mentioned above.

Shepherding is the main goal of the shepherds. Shepherds have always been known for their wealth of life experience.

The shepherd is described as the sultan of the pasture among the people. This definition is embedded in folklore like:

The farmer is the sultan of the land

A shepherd is a pasture sultan.

Shepherds graze on pastures, on hills and in deserts. They are people in the public service. Shepherds devote their lives to the good of the people. They graze in the summer, not in the hot summer, the cold in the winter. As a result, people have a special respect for shepherds.

Shepherding is the first profession in human history. That is why attitude to this profession occupies a special place in folklore genres. There is no genre in folklore unless there is a pastoral image.

A shepherd is a professional who delivers meat to the people. They provide the people with food. This is why the profession is highly valued. Even folk proverbs contain proverbs that encourage the younger generation to become pastors.

In ancient times, shepherds led their livestock through star movements, stars, and changes in nature. The shepherds followed the livestock calendar directly when grazing the livestock and bringing it back from the pasture. M. Juraev made special mention of this. In short, the "Livestock Calendars" calendar is important in the life of the pastors. It is still very old and still exists in the life of the pastors. The attitude of shepherds is found in almost every genre of the Uzbek follower. Particularly among the songs created for children is the description of wealth; The secrets of feeding sheep, horses, and goats, as well as songs about this subject are of particular interest. These songs are mainly intended to introduce children to a particular pet, to teach its characters. Of course, these kinds of songs have been created and widely popular among livestock people.

Shepherd's image and realities of pastoral life are also reflected in children's folk games. Because adults tell children about life through play. In the folk games created with this need, shepherds and children, the herds and the herdsmen are brought together. An example of this is the game "Shepherd and herd". In games such as "Wolves and Goats," "Sheep and Wolf", "Shepherd and Crushed", children are taught to be sophisticated, agile, sophisticated, and fearless in protecting the herd from predators, and on this basis, they are given a well-known educational effect. In short, the attitude of shepherds to the life of shepherds can be seen in many popular genres of Uzbek folklore, such as proverbs, puzzles, songs, myths and legends, fairy tales, poems, and even children's songs and games. The image of the shepherd is reflected in the epic art of the Uzbek folk epic.

Because they are told by grandchildren, adults, especially grandparents, they often have grandparents. Including:

My birth gave birth to white eggs,

My grandfather hit - he didn't break,

My grandmother hit - it didn't break.

Mouse hit with tail - broken!

Grandpa cried,

My grandmother cried.

Chicken chills,

The mice shouted.

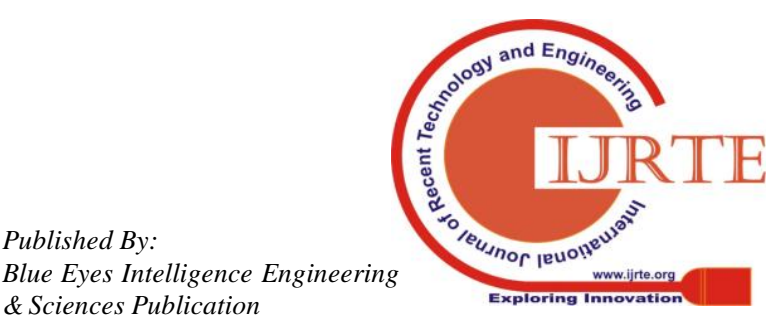


In goats with the image of mom, goat's image is often found:

"Where are you going, my daughter?"

- I'll go to Mom's house.

"What will your mom give you?"

- Goat's milk provides.

- Goat does not have milk

He has no lice.

One of the most common characters in entertainment is the image of the drug. The image of Bangi is interpreted in a satirical manner in curious. In this way children are introduced as addicts - bad people. This is the basis for raising children in the spirit of youth and the hatred of smokers. In fun, drugs are described as someone who has never been able to achieve anything in life.

One of the most important features of the funs is that of course, the image of a child is involved. Because the main content of the fun relates to the child and the environment surrounding him. Taking this into consideration, Babushkina says of her: "The images of this folk poetry are always connected with life, with the feelings of the child."

Before understanding each phenomenon of the world, the children reflect on their specifics. Therefore, every moving image, first of all, in the children's curiosities will be associated with the child. In this context, the animals are represented by animals, toys, and human beings that are familiar to children.

Funs are often seen in the personalization of totem and cult creatures. Therefore, it is impossible to fully agree with $\mathrm{O}$. Safarov on the importance of randomness in the fun. Hence, the names of totem and cult animals are mentioned in curiosity. Specifically, images such as horses, camels, dogs, monkeys, geese and others were not chosen at random.

It is intended that children remember and remember the names of animals, who are regarded as totem and cult from an early age. In addition, children do not set a boundary between themselves and the animal. That is why young children like to play with dogs, cats, lambs, goats and calves. They speak and speak freely as if they were human beings. There is no doubt that animals do not understand what they are saying. On the contrary, he thinks he understands. With this in mind, adults are more likely to use the animal image in curiosities and to reveal some of the deficiencies that humans face through animal behavior.

Through this curiosity, the children are drawn to the main characters of the frog: to make a voice over time and to have a crooked head. Her character is shown as a joke and a joke. It was as if the frog went to war and was wearing a helmet, an iron hat, to protect his head from bullets. This expression, in turn, can instill a hatred of war in the hearts of children.

It is true that this curiosity can sometimes be said to have children with defects in their heads. It also focuses on children who talk a lot, who have a crook or cradle, or who have a crooked head.

In this curiosity, children are warned of the harm that sparrows can cause to farming. "Camel, where's the salt?"

Go ahead, the sheep.

He came to suck, I am full.
I have been sucked on the ground,

He gave her a pillow.

I gave the robe to the black cow

The black cow gave milk.

I gave Cuban milk,

He drank most of it.

It is interesting to note the shift from image to image in the form of "camel-cow-butterfly". It is noteworthy that these images were developed from adult to small. In funs, it is sometimes observed that the opinion is expressed as follows:

Bread closed oven.

Like a sieve given to a people,

As the bride gave to the bride,

He gave me like a nail.

I shot at the door,

I'm in the hole. [1,98]

The reality of the fun is enjoyable. The picture shows that a boy with a sliver of bread snapped his nails into the door. Whereas there are some taboos and rituals related to bread. They are often told that they are punished severely by bread. That is why the lyric hero who has hit his forehead for throwing his provision in the door is expressing regret.

Some funs also show the opposite. It is, in contrast, a small image or an image of a creature after such a large image.

Animals are sometimes described as animals doing human work. For example, a cat can sew a shirt, and a dog is a watchman.

\section{RESULT}

1. The genre of the genre of people (such as yanga, elder grandparents, grandmothers, children, shepherds, peasants, khan, drug addicts) was revealed.

2. The fun was revealed through examples such as creatures (camels, wolves, donkeys, goats, goats, dogs, cats, calves, lambs, rabbits, ravens, storks, lice).

3. The image of events takes a special place in the fun

4. It has been shown that the funs have a unique artistic and aesthetic function.

5. In funs, there is mainly a shift from image to image, from idea to thought.

\section{CONCLUSION}

A 1. The art of fun is not inferior to that of other peculiar songs, but is even more perfect. They use traditional images that are clear and understandable to children. One reality connects to the other and forms an intellectual chain link. From image to image, from thought to thought. This way their size will be extended. 2. The world of fun characters is rich and diverse. In addition to the child's image, the adult character also plays a special role. It is one of the most common characters, especially in side funs. They are often criticized by the yang image. Hakka (raven) is interpreted as a constant enemy of the fire. 
In this case, the hack is presented as an evil, and the other side is a shaman - a fighter against evil. In some funs, the image of the yang is expressed by the ancient levirate custom.

3. The characters of the funs are people (yanga, brother, elder grandmother, grandmother, child, girl, shepherd, farmer, khan, gang, Hasan-Husan, Shady lamb, etc.), creatures (camels, wolves, donkeys, sheep, goats, goats, dogs, cats, calves, lambs, rabbits, lice, fish), birds and birds (ravens, ravens, storks, quails, roosters, chickens, chickens), sky lights (sun, moon, stars), natural phenomena ( wind, snow, rain, cloud, fog), things (whip, sword, knife, oven, egg, bowl, cradle, beetle), trees, plants and fruits (willow, berry, red apple, red flower), mythological space (Eram Garden, Alatagh), mythological images (pari, Ajina, Yalmogiz), etc. have a special role and play a unique artistic and aesthetic role. The following is mentioned in funs.

\section{REFERENCES}

1. Boycheck. Uzbek folk art. Multiple drops. Children's folklore.

2. Labor songs. Developed by: Oxunjon Safarov and Kamol Ochilov. - T .: Publishing House of Literature and Art named after Gafur Gulom, 1984. - p. $46-57$.

3. Jabborov I. Ethnography of the Uzbek people. - T .: Instructor, 1994. B.109-113.

4. Juraev M., Shomusarov Sh. Uzbek mythology and Arabic folklore. - T .: Science, 2001. - 136 p.

5. Juraev M., Hudoykulova L. Ceremony. A brief overview of the customs and traditions of the Uzbek people. - T .: Publishing House of the National Library of Uzbekistan named after Alisher Navoi, 2008. -B.10, 45-65,108.

6. Musaqulova A. Historical bases and art of Uzbek national lyric. Filal. science. d-ri ... diss. autoref. - T., 1995. - B.21.

7. Musaqulov A. The Uzbek national lyrics. - T .: Science, 2010. - B.92.

8. Uzbek folk fairy tales. Created by Sh.Turdimov. - T .: Publishing House of the Central Committee of the Communist Party of Uzbekistan, 1990. B.202-207.

9. Uraeva D. Attractive world of children's folklore / Oxunjon Safarov. Creative portrait. - T .: Editor, 2010. - B.52.

10. Kayumov O. Pari's image in Uzbek folklore: Filol. science. nomz .... diss. autoref. - T., 1999. - B.25.

11. Gazibaev T., Sabirov A. Samples of Namangan folklore. - Namangan, 1993. - B.54. 